Review

\title{
Adjunctive Application of Antimicrobial Photodynamic Therapy in Nonsurgical Periodontal Treatment: A Review of Literature
}

\author{
Takeshi Kikuchi ${ }^{1, *}$, Makio Mogi ${ }^{2}$, Iichiro Okabe ${ }^{1}$, Kosuke Okada ${ }^{\mathbf{1}}$, Hisashi Goto ${ }^{\mathbf{1}}$, \\ Yasuyuki Sasaki ${ }^{1}$, Takeki Fujimura ${ }^{1}$, Mitsuo Fukuda ${ }^{1}$ and Akio Mitani ${ }^{1, *}$
}

1 Department of Periodontology, School of Dentistry, Aichi Gakuin University, Nagoya, Aichi 464-8651, Japan; E-Mails: ag133d04@dpc.agu.ac.jp (I.O.); ag133d03@dpc.agu.ac.jp (K.O.); ag123d14@dpc.agu.ac.jp (H.G.); ag143d09@dpc.agu.ac.jp (Y.S.); takeki@dpc.agu.ac.jp (T.F.); fukuda-m@dpc.agu.ac.jp (M.F.)

2 Department of Medicinal Biochemistry, School of Pharmacy, Aichi Gakuin University, Nagoya, Aichi 464-8650, Japan; E-Mail: makio@dpc.agu.ac.jp

* Authors to whom correspondence should be addressed;

E-Mails: tkikuchi@dpc.aichi-gakuin.ac.jp (T.K.); minita@dpc.agu.ac.jp (A.M.);

Tel./Fax: +81-52-759-2150 (T.K. \& A.M.).

Academic Editor: Ying-ying Huang

Received: 30 July 2015 / Accepted: 8 October 2015 / Published: 13 October 2015

\begin{abstract}
Periodontal disease is caused by dental plaque biofilms, and the removal of these biofilms from the root surface of teeth plays a central part in its treatment. The conventional treatment for periodontal disease fails to remove periodontal infection in a subset of cases, such as those with complicated root morphology. Adjunctive antimicrobial photodynamic therapy (aPDT) has been proposed as an additional treatment for this infectious disease. Many periodontal pathogenic bacteria are susceptible to low-power lasers in the presence of dyes, such as methylene blue, toluidine blue $\mathrm{O}$, malachite green, and indocyanine green. aPDT uses these light-activated photosensitizer that is incorporated selectively by bacteria and absorbs a low-power laser/light with an appropriate wavelength to induce singlet oxygen and free radicals, which are toxic to bacteria. While this technique has been evaluated by many clinical studies, some systematic reviews and meta-analyses have reported controversial results about the benefits of aPDT for periodontal treatment. In the light of these previous reports, the aim of this review is to provide comprehensive information about aPDT and help extend knowledge of advanced laser therapy.
\end{abstract}


Keywords: photodynamic therapy; antimicrobial photodynamic therapy; periodontal treatment; periodontal disease; periodontal pathogenic bacteria; low-power laser; photosensitizer

\section{Introduction}

Photodynamic therapy (PDT) utilizes singlet oxygen and free radicals produced by a light-activated photosensitizer to kill microbes. The photochemical process is initiated by a low-power laser/light at a relevant wavelength to excite the photosensitizer. The ground state photosensitizer absorbs light, resulting in a singlet state that can lose energy by fluorescence or undergo intersystem crossing to a triplet state with longevity. The latter state leads to a photochemical reaction that induces singlet oxygen, free radicals, and superoxide, which are cytotoxic, thereby inducing microbial killing [1] (Figure 1).

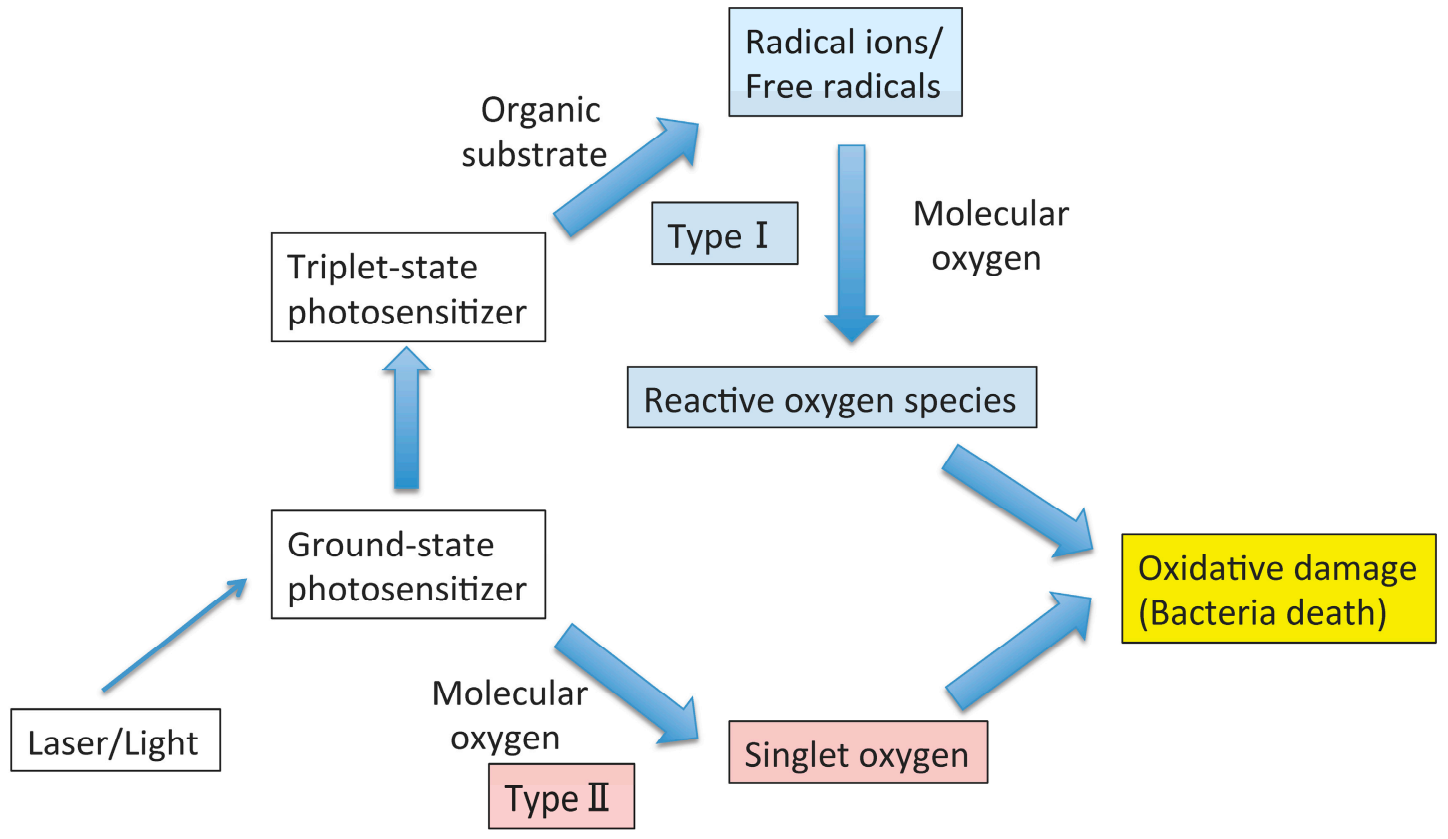

Figure 1. Photochemical mechanisms in photodynamic therapy.

The initial application of PDT for selective toxicity was attempted more than a hundred years ago [2-4]. The discovery of antibiotics caused considerable stagnation for applications of PDT to infectious diseases in the 1940s. However, the recent rise in antibiotic resistance has shifted attention back to PDT. Interestingly, while PDT can eliminate antibiotic-resistant microbes [5], there is no information about microbes developing resistance to PDT [6].

Although an ancestor of PDT seemed initially and accidentally discovered for its antimicrobial effects [4], recent work on a practical PDT has focused on developing it as a cancer therapy [7,8]. The generated reactive oxygen species are toxic to cancer cells and lead to cellular death.

\section{Antimicrobial PDT}

Photosensitizers in antimicrobial PDT (aPDT), such as porphyrins, phthalocyanines, and phenothiazines (e.g., toluidine blue $\mathrm{O}$ and methylene blue), can target both Gram-positive and -negative 
bacteria by bearing a positive charge [9-11], suggesting that aPDT may be useful in oral applications, especially for periodontal treatment [12-14]. Activation of the photosensitizer can be induced by portable diode lasers that are cost effective compared with other types of lasers. Several studies have shown that periodontal bacteria are susceptible to PDT in planktonic cultures [15-24], plaque scrapings [23,25], and biofilms [23,24,26,27] using methylene blue [17,20,26], methylene blue-loaded polymeric nanoparticles [23], toluidine blue $\mathrm{O}[15,16,18,20,25,26]$, phthalocyanine [26,27], hematoporphyrin $\mathrm{HCl}$ [26], hematoporphyrin ester [26], a conjugate of poly-L-lysine and the photosensitizer chlorin e6 [19], indocyanine green [22], indocyanine green-loaded nanospheres [21], and safranine $O$ [24] (Table 1). However, other studies have demonstrated incomplete destruction of oral pathogens [28-32].

Table 1. Photosensitizers used in antimicrobial photodynamic therapy (aPDT) for periodontal microbes.

\begin{tabular}{|c|c|c|c|}
\hline $\begin{array}{l}\text { Author and } \\
\text { Year (Ref.) }\end{array}$ & Photosensitizer & Samples/Bacterial Strain & Conclusion \\
\hline $\begin{array}{c}\text { Bhatti et al., } \\
2002[15]\end{array}$ & Toluidine blue $\mathrm{O}$ & $\begin{array}{l}\text { Planktonic culture/ } \\
\text { Porphyromonas gingivalis }\end{array}$ & $\begin{array}{l}\text { Disruption of membrane functions associated with } \\
\text { a decrease in membrane fluidity may contribute to the } \\
\text { bactericidal effect of light-activated toluidine blue }\end{array}$ \\
\hline $\begin{array}{c}\text { Bhatti et al., } \\
1997[16]\end{array}$ & Toluidine blue $\mathrm{O}$ & $\begin{array}{l}\text { Planktonic culture/ } \\
\text { Porphyromonas gingivalis }\end{array}$ & $\begin{array}{l}\text { In the presence of toluidine blue } \mathrm{O} \text {, a light } \\
\text { dose-dependent increase in bacterial killing was } \\
\text { attained ( } 100 \% \text { killing at } 4.4 \mathrm{~J})\end{array}$ \\
\hline $\begin{array}{l}\text { Chan et al., } \\
2003 \text { [17] }\end{array}$ & Methylene blue & $\begin{array}{l}\text { Planktonic culture/Actinobacillus } \\
\text { actinomycetemcomitans, } \\
\text { Fusobacterium nucleatum, } \\
\text { Porphyromonas gingivalis, } \\
\text { Prevotella intermedia, and } \\
\text { Streptococcus sanguinis }\end{array}$ & $\begin{array}{l}\text { Using a diode laser of appropriate power and wavelength } \\
\text { to deliver } 60 \mathrm{~s} \text { of irradiation could be a useful adjunct } \\
\text { therapy with mechanical debridement for the prevention } \\
\text { of re-colonization of subgingival lesions by pathogenic } \\
\text { microorganisms }\end{array}$ \\
\hline $\begin{array}{l}\text { Matevski et al., } \\
\qquad 2003[18]\end{array}$ & Toluidine blue $\mathrm{O}$ & $\begin{array}{l}\text { Planktonic culture/ } \\
\text { Porphyromonas gingivalis }\end{array}$ & $\begin{array}{l}\text { The data indicated that aPDT using a conventional light } \\
\text { source was at least as effective as laser-mediated } \\
\text { treatment in vitro }\end{array}$ \\
\hline $\begin{array}{l}\text { Souko et al., } \\
1998 \text { [19] }\end{array}$ & $\begin{array}{l}\text { A conjugate between } \\
\text { poly-L-lysine and the } \\
\text { photosensitizer chlorin e6 }\end{array}$ & $\begin{array}{l}\text { Planktonic culture/ } \\
\text { Porphyromonas gingivalis and } \\
\text { Actinomyces viscosus }\end{array}$ & $\begin{array}{l}\text { The cationic pL-ce } 6 \text { conjugate may have applications in } \\
\text { PDT of periodontal disease }\end{array}$ \\
\hline $\begin{array}{c}\text { Wilson et al., } \\
1993 \text { [20] }\end{array}$ & $\begin{array}{l}\text { Toluidine blue } \mathrm{O} \text {; } \\
\text { Methylene blue }\end{array}$ & $\begin{array}{l}\text { Planktonic culture/ } \\
\text { Porphyromonas gingivalis, } \\
\text { Fusobacterium nucleatum, } \\
\text { and Actinobacillus } \\
\text { actinomycetemcomitans }\end{array}$ & $\begin{array}{l}\text { Low doses of light }\left(22 \mathrm{~J} / \mathrm{cm}^{2}\right) \text { were effective to kill bacteria } \\
\text { in vivo, and the technique may be useful to eliminate } \\
\text { periodontopathogenic bacteria from diseased sites }\end{array}$ \\
\hline $\begin{array}{l}\text { Nagahara et al., } \\
2013[21]\end{array}$ & $\begin{array}{c}\text { Indocyanine green-loaded } \\
\text { nanospheres }\end{array}$ & $\begin{array}{l}\text { Planktonic culture/ } \\
\text { Porphyromonas gingivalis }\end{array}$ & $\begin{array}{l}\text { ICG-Nano/c with low-level diode laser }(0.5 \mathrm{~W} ; 805 \mathrm{~nm}) \\
\text { irradiation might be useful as a potential photodynamic } \\
\text { periodontal therapy }\end{array}$ \\
\hline $\begin{array}{l}\text { Topaloglu et al., } \\
2013 \text { [22] }\end{array}$ & Indocyanine green & $\begin{array}{l}\text { Planktonic culture/ } \\
\text { Staphylococcus aureus and } \\
\text { Pseudomonas aeruginosa }\end{array}$ & $\begin{array}{l}\text { The combination of ICG and 809-nm laser light was } \\
\text { an effective antibacterial method to destroy } \\
\text { antibiotic-resistant strains of Gram-positive and } \\
\text {-negative bacteria }\end{array}$ \\
\hline
\end{tabular}


Table 1. Cont.

\begin{tabular}{|c|c|c|c|}
\hline $\begin{array}{l}\text { Author and } \\
\text { Year (Ref.) }\end{array}$ & Photosensitizer & Samples/Bacterial Strain & Conclusion \\
\hline $\begin{array}{l}\text { Klepac-Ceraj et al., } \\
2011 \text { [23] }\end{array}$ & $\begin{array}{l}\text { Methylene blue-loaded } \\
\text { polymeric nanoparticles }\end{array}$ & $\begin{array}{l}\text { Planktonic culture, plaque } \\
\text { scraping, and biofilm/human } \\
\text { dental plaque bacteria }\end{array}$ & $\begin{array}{l}\text { Cationic methylene blue-loaded poly lactic-co-glycolic } \\
\text { acid nanoparticles showed the potential to be used as } \\
\text { carriers of methylene blue for photodynamic } \\
\text { periodontal therapy Systems }\end{array}$ \\
\hline $\begin{array}{l}\text { Voos et al., } \\
2014[24]\end{array}$ & Safranine $\mathrm{O}$ & $\begin{array}{l}\text { Planktonic culture and biofilms/ } \\
\text { Streptococcus gordonii, } \\
\text { Streptococcus mutans, } \\
\text { Fusobacterium nucleatum, } \\
\text { Aggregatibacter } \\
\text { actinomycetemcomitans, and } \\
\text { Porphyromonas gingivalis }\end{array}$ & $\begin{array}{l}\text { Oral pathogenic species in planktonic solution were } \\
\text { suppressed significantly by antimicrobial photodynamic } \\
\text { periodontal therapy with safranin O. Particularly for } \\
\text { bacteria in a } 24-\mathrm{h} \text { ex vivo biofilm, this method was more } \\
\text { effective than treatment with } 0.2 \% \mathrm{CHX} \text {. } \\
\text { Both antibacterial treatments did not show any } \\
\text { significant effect on the biofilm cultured for } 72 \mathrm{~h}\end{array}$ \\
\hline $\begin{array}{c}\text { Sarkar et al., } \\
1993 \text { [25] }\end{array}$ & Toluidine blue $\mathrm{O}$ & $\begin{array}{l}\text { Plaque scraping/human dental } \\
\text { plaque bacteria }\end{array}$ & $\begin{array}{l}\text { The use of low-power lasers, in conjunction with } \\
\text { appropriate photosensitizers, may be a useful adjunct } \\
\text { therapy to mechanical debridement for treating } \\
\text { inflammatory periodontal diseases if similar } \\
\text { effectiveness against subgingival plaque bacteria } \\
\text { can be achieved in vivo }\end{array}$ \\
\hline $\begin{array}{c}\text { Dobson et al., } \\
1992[26]\end{array}$ & $\begin{array}{c}\text { Methylene blue; } \\
\text { Toluidine blue O; } \\
\text { Phthalocyanine; } \\
\text { Hematoporphyrin } \mathrm{HCl} \text {; } \\
\text { Hematoporphyrin ester }\end{array}$ & $\begin{array}{l}\text { Biofilms/Streptococcus } \\
\text { sanguinis, Porphyromonas } \\
\text { gingivalis, Fusobacterium } \\
\text { nucleatum, and Actinobacillus } \\
\text { actinomycetemcomitans }\end{array}$ & $\begin{array}{l}\text { Lethal photosensitization may be effective in eliminating } \\
\text { periodontopathogenic bacteria from dental plaque }\end{array}$ \\
\hline $\begin{array}{c}\text { Wood et al., } \\
1999 \text { [27] }\end{array}$ & Phthalocyanine & $\begin{array}{l}\text { Biofilms/Human dental } \\
\text { plaque bacteria }\end{array}$ & $\begin{array}{l}\text { Confocal scanning laser microscopy of the biofilms } \\
\text { showed that the photosensitizer was taken up into the } \\
\text { biomass of the biofilm, and that significant cell death } \\
\text { was caused by PDT }\end{array}$ \\
\hline
\end{tabular}

Toluidine blue $\mathrm{O}$ interacts with lipopolysaccharides present in the cell membrane of Gram-negative bacteria, even in the absence of light. However, upon exposure to a wavelength of $630 \mathrm{~nm}$, it has maximal absorption and good photodynamic properties for killing various types of microbes in vitro [33]. Methylene blue shows maximal absorbance by exposure to a wavelength of $660 \mathrm{~nm}$ [17]. Indocyanine green has a high absorption at a wavelength of $805 \mathrm{~nm}$ by low-level diode laser irradiation [21].

Gram-negative bacteria are largely resistant to many photosensitizers used in aPDT [34]; however, some microbial species, such as oral black-pigmented bacteria, contain naturally occurring photosensitizers and are very susceptible to aPDT. It was demonstrated that the light band ranging from 380 to $520 \mathrm{~nm}$ induces a three-fold reduction in the growth of Porphyromonas gingivalis, Prevotella intermedia, Prevotella nigrescens, and Prevotella melaninogenica in dental plaque samples obtained from human subjects with chronic periodontitis [35]. Based on these findings, the same group proposed a phototherapeutic strategy by which daily exposure to visible light would gradually suppress the numbers of black-pigmented bacteria, leading to a shift of the microbial environment toward a healthy environment [36]. 


\section{PDT as a Non-Antibiotic Antimicrobial Therapy}

Generally, the metabolism of bacteria within a biofilm is notably more self-sufficient than that of planktonic cells. Furthermore, bacteria within a biofilm are better protected from harmful attacks. For example, oral-pathogenic species in a planktonic solution were significantly suppressed by either aPDT or chlorhexidine (CHX); however, in an ex vivo biofilm, aPDT was more effective at suppressing the bacteria than treatment with CHX [24]. Additionally, because of the low bacterial metabolic activity in the bulk layer of biofilm, lower amounts of drugs are absorbed and the reaction is weak. Because the surface layer of a biofilm also degenerates under the effects of antibacterial agents, further diffusion into the bulk layer is inhibited [37]. The reduced susceptibility of complex oral biofilms to aPDT may require the development of novel delivery and targeting approaches. Evolving therapeutic strategies for biofilm-related infections include the use of substances designed to target the biofilm matrix, non-proliferating bacteria within biofilms, and/or quorum-sensing bacteria [38]. The use of bacteriophages [39] and naturally occurring or synthetic antimicrobial peptides [40] may allow bacterial targeting without the emergence of resistance.

Currently, microbial viability recovery or any resistance mechanisms against aPDT has not yet been reported. Tavares et al. [41] performed a study investigating those issues and their results suggest that aPDT using Tri-Py ${ }^{+}-\mathrm{Me}-\mathrm{PF}$ represents a promising approach to efficiently destroy bacteria since after a single treatment these microorganisms do not recover their viability and after ten generations of partially photosensitized cells neither of the bacteria develop resistance to the photodynamic process [41]. aPDT could rather be used to treat arthritis in mice caused by bioluminescent methicillin-resistant Staphylococcus aureus (MRSA) [42]. The advantages of targeted therapy are becoming more apparent, and the use of light alone, antibody- and bacteriophage-photosensitizer conjugates, and non-antibody-based targeting moieties, such as nanoparticles, are gaining increasing attention.

\section{Periodontitis}

Periodontitis is a common disease that causes tooth loss, and chronic inflammation induced by bacterial infection is the major cause of periodontium destruction [43]. Infection control by tooth surface debridement using hand instruments is a basic technique for therapy, and additional surgical procedures are sometimes needed. Systemic antimicrobial therapy is occasionally used for intractable disease. However, its side effects, including antibiotic resistance, should always be considered. Another option for antimicrobial therapy is local delivery to periodontal pockets. However, there are some disadvantages to this approach, such as the necessity for repeated treatments and its utility for small ranges of the periodontium. Additionally, the applied antimicrobial agents can cause decalcification and root surface softening [44].

It has been recognized that specific bacteria, rather than non-specific bacteria, are linked to chronic and aggressive periodontitis, which has led to the development of antimicrobial treatments for reducing these particular bacteria. It is difficult to visually identify the bacteria that are causing subgingival disease; thus, mechanical debridement solely cannot remove all sources of infection. Furthermore, dentinal tubes are opened by mechanical debridement. As a result, the remaining 
periodontal bacteria are able to penetrate into the dentinal tubes, and it is possible to confirm the formation of a biofilm shortly after treatment $[45,46]$.

Some patients continue to show destruction of periodontal tissue after mechanical debridement. These patients often have risk factors, such as smoking, diabetes, hereditary factors, and systemic disease, which are accompanied by persistent infection with one or more specific periodontal pathogenic bacteria [47-49].

\section{Periodontitis and Laser Treatment}

Although the photosensitizers used in aPDT are generally activated by laser/light at specific wavelengths, sometimes the lasers used for periodontal treatment do not rely on the activation of a photosensitizer but on the interaction of the laser alone for the treatment of periodontal disease. There are several types of lasers utilized for periodontal treatment. $\mathrm{CO}_{2}$ lasers have mild root conditioning, detoxification, and bactericidal effects on contaminated root surfaces [50,51], but unfortunately, they also have the potential to produce thermal damage in the periodontal pocket and surrounding tissues [52]. The application of Nd:YAG and diode lasers similarly has bactericidal and detoxification effects, and this technique shows clinical benefits as an adjunct to nonsurgical periodontal therapy [53-58]. A diode laser is also utilized for low-level laser therapy, which is expected to promote healing by collagen synthesis and angiogenesis [59,60]. The better healing is observed when this is utilized for periodontal surgery [61,62]. The Er:YAG laser has the most clinically useful effects, including calculus and cementum bounding endotoxin removal, bactericide, and detoxification [63-65].

\section{PDT as a Light Sterilization Therapy for Periodontitis}

Bonito et al. showed that mechanical debridement cannot completely remove pathogenic bacteria [66]. Additionally, mechanical debridement alone only temporarily reduces the bacterial infection and may result in a return to pre-treatment levels in less than two weeks $[45,46]$. In the past decade, the limitations of conventional periodontal therapy have given rise to many attempts to introduce aPDT as an alternative treatment of chronic periodontitis [67-70]. aPDT has been confirmed to be effective as a non-antibiotic antimicrobial therapy $[71,72]$.

Two main advantages are frequently cited for aPDT in comparison with other periodontal treatments. In aPDT, a photosensitizer placed directly into the pocket can be activated via an optical fiber also placed directly in the pocket, which helps to avoid damaging adjacent host tissue [73]. Additionally, the effects of aPDT are initiated by exposure to a light source, thus preventing the selection of resistant bacterial species [74]. Importantly, the eradication of biofilms and inactivation of inflammatory cytokines by aPDT has proven to be both effective and safe.

Human studies have produced contrasting results [12,69,75-78], and some systematic reviews have only partly discussed the adjunctive effect of aPDT [43,79]. A meta-analysis by Atieh [80] revealed supportive data for the potential improvements of using aPDT in conjunction with scaling and root planning (SRP) in periodontal treatment. That study found the association between those treatments is significantly related to a greater clinical attachment gain and a reduction in probing depth. Sgolastra et al. also conducted a systematic review indicating that the adjunctive use of aPDT and subgingival SRP 
can provide additional benefits in terms of reductions in pocket depth and gains in the clinical attachment level [12]. These benefits of combined treatment were observed only at the three-month follow-up time point. In contrast, no significant differences were observed at six months post-treatment. However, this finding is likely related to the small number of included studies that reported a follow-up time of six months. The most recent systematic review concluded that PDT with a diode laser adjunctive to SRP has beneficial effects with a moderate level of certainty (Table 2) [14].

Table 2. Systematic review of the adjunctive effects of antimicrobial photodynamic therapy (aPDT) for periodontal treatment (scaling root planing (SRP)).

\begin{tabular}{|c|c|c|}
\hline Author and Year (Ref.) & Treatment Arms & Results \\
\hline Smiley et al., 2015 [14] & $\begin{array}{l}\text { Test: SRP + aPDT; } \\
\text { Control: SRP }\end{array}$ & $\begin{array}{l}\text { aPDT with a diode laser adjunctive to SRP had a beneficial } \\
\text { effect with a moderate level of certainty }\end{array}$ \\
\hline Sgolastra et al., 2013 [12] & $\begin{array}{l}\text { Test: SRP + aPDT; } \\
\text { Control: SRP }\end{array}$ & $\begin{array}{l}\text { The use of adjunctive aPDT with conventional SRP provided } \\
\text { short-term benefits }\end{array}$ \\
\hline Sgolastra et al., 2013 [79] & $\begin{array}{l}\text { Test 1: SRP + aPDT; } \\
\text { Test 2: aPDT; } \\
\text { Control: SRP }\end{array}$ & $\begin{array}{l}\text { The use of aPDT adjunctive to conventional treatment provided } \\
\text { short-term benefits. There was no evidence of effectiveness for } \\
\text { the use of aPDT as an alternative to SRP }\end{array}$ \\
\hline Azarpazhooh et al., 2010 [43] & $\begin{array}{l}\text { Test 1: SRP + aPDT; } \\
\text { Test 2: aPDT; } \\
\text { Control: SRP }\end{array}$ & $\begin{array}{l}\text { aPDT as an independent treatment or an adjunct therapy to SRP } \\
\text { was not superior to SRP }\end{array}$ \\
\hline Atieh et al., 2010 [80] & $\begin{array}{l}\text { Test: SRP + aPDT; } \\
\text { Control: SRP }\end{array}$ & $\begin{array}{l}\text { The use of aPDT in conjunction with SRP was associated with } \\
\text { significant clinical parameter improvements }\end{array}$ \\
\hline
\end{tabular}

\section{Animal Studies of the Effects of aPDT on Periodontitis}

Favorable results with aPDT as an adjunct therapy to SRP have been reported in experimental rat periodontitis $[67,68,81-84]$. The progression of experimental periodontitis was substantially reduced by aPDT both radiographically and histologically [68]. Similar positive results were also obtained in furcation areas $[81,82]$. The rats treated with aPDT exhibited reduced numbers of tartrate-resistant acid-phosphatase-positive cells, weak immunoreactivity to the receptor activator nuclear factor- $\mathrm{kB}$ ligand, and strong osteoprotegerin immunoreactivity [83,84]. The efficacy of aPDT was also confirmed in periodontal infection of a beagle dog model $[85,86]$. Improvement in periodontal healing, associated with collagen organization, inflammatory cell infiltration, and bone loss, with the addition of aPDT has also been reported [87].

Experimental periodontitis models have revealed the microbiological and cytokine profiles resulting from aPDT [86]. A single application of aPDT, SRP, or the combination of both treatments all led to reductions in the levels of most bacterial species after one week [86]. However, increases in $P$. intermedia, $P$. nigrescens, and T. forsythia were observed following aPDT alone or in conjunction with SRP. After four weeks, regrowth of $P$. gingivalis and $T$. denticola were observed for all treatments, but a remarkable reduction of A. actinomycetemcomitans was observed following application of aPDT. Additionally, reductions in cytokine levels and bacterial numbers were observed regardless of the treatment used. The authors inferred that the different periodontal treatments tested 
had distinct mechanisms of action against the bacteria and, thus, might have additive or even synergistic effects [86].

\section{Effects of PDT on the Host}

A possible concern for the clinical application of PDT is the potential photocytotoxicity to host cells. However, it has been demonstrated that the doses of light needed for killing bacteria in PDT are much lower than those that are toxic for keratinocytes and fibroblasts [88]. In fact, some beneficial effects of PDT have even been reported in periodontal ligament cells, such as inhibition of inflammatory mediators, thus favoring cellular chemotaxis and the promotion of local vasodilation and angiogenesis [89]. In terms of the modulation of innate immunity, PDT acts on neutrophils and promotes their migration and integration [90]. PDT also inactivates host-derived cytokines, such as tumor necrosis factor- $\alpha$ and interleukin-1 $\beta$, to inhibit E-selectin activation in endothelial cells [91]. PDT affects antigen-presenting cells, such as macrophages and Langerhans cells, by reducing their capacity to activate T-lymphocytes and weakens the inflammatory response [92]. Seguier et al. [92] also found that PDT targets different cell populations depending on the type of photosensitizer used in the treatment (e.g., liposomes and nanoemulsions). Fujimura et al. reported the effects of PDT on epithelial cells by irradiation with a low-level diode laser and an indocyanine green-loaded nanosphere coated with chitosan (ICG-Nano/c) [93]. The migration of epithelial cells and expression of Del-1 were significantly increased by diode laser irradiation with or without ICG-Nano/c compared with those in the control. These results suggest that low-level diode laser irradiation with or without ICG-Nano/c can suppress excessive inflammatory responses via these mechanisms in addition to its antimicrobial effect.

\section{Effect of aPDT on Periodontitis with an Unusual Host Response}

Some studies on the effects of aPDT in patients with aggressive periodontitis [94-98] have reported favorable results for the state of human subgingival flora. It has been suggested that both aPDT and SRP might be beneficial for nonsurgical treatment of aggressive periodontitis [94]. The most recent report from Moreira et al. showed additional clinical, microbiological, and immunological benefits of aPDT in patients with aggressive periodontitis [97].

Under specific periodontal conditions, aPDT can be a useful tool for antimicrobial treatment when conventional SRP is not effective [67] in medically compromised patients [67,99,100], children, and disabled people [27]. It has also been suggested that aPDT may be useful as an adjunct therapy to SRP for persistent periodontitis that is strongly related to the presence of $P$. gingivalis and $P$. intermedia [101]. aPDT counteracts the impaired healing in diabetic and/or immunosuppressed animals [102-104]. Additionally, aPDT has been shown to reduce bone loss and promote the repair of bone tissue, which is modulated by immunosuppressive drugs [105-108]. The influence of aPDT on periodontal bone loss related to diabetes in rats was initially reported by Almeida et al. [67]. Their histometric data showed that aPDT using toluidine blue $\mathrm{O}$ and a GaAlA laser produced less bone loss compared with rats treated only with scaling root planing or toluidine blue $\mathrm{O}$ in both diabetic and non-diabetic rats by increasing the diffusion of oxygen through the tissue. This effect favored the repair process because collagen production by fibroblasts in the extracellular space occurs only in the presence of high rates of oxygen pressure. 


\section{Conclusions}

While many preferable outcomes in vitro and in vivo have been demonstrated for the use of aPDT, there is some variability in the results of this technique in clinical practice. However, the majority of systematic reviews conclude that the inclusion of aPDT as an adjunct to nonsurgical periodontal treatment seems to be therapeutically useful. Further studies of aPDT are needed for establishing this as a beneficial adjunct treatment for periodontitis.

\section{Author Contributions}

Takeshi Kikuchi conducted the literature review and wrote the manuscript. Makio Mogi, Iichiro Okabe, Kousuke Okada, Hisashi Goto, Yasuyuki Sasaki, Takeki Fujimura and Mitsuo Fukuda contributed to writing and reviewing. Akio Mitani contributed to writing, proofreading, and reviewing.

\section{Conflicts of Interest}

The authors declare no conflict of interest.

\section{References}

1. Kharkwal, G.B.; Sharma, S.K.; Huang, Y.Y.; Dai, T.; Hamblin, M.R. Photodynamic therapy for infections: Clinical applications. Lasers Surg. Med. 2011, 43, 755-767.

2. Wilson, J.J.; Jones, H.; Burock, M.; Smith, D.; Fraker, D.L.; Metz, J.; Glatstein, E.; Hahn, S.M. Patterns of recurrence in patients treated with photodynamic therapy for intraperitoneal carcinomatosis and sarcomatosis. Int. J. Oncol. 2004, 24, 711-717.

3. Matsubara, T.; Kusuzaki, K.; Matsumine, A.; Satonaka, H.; Shintani, K.; Nakamura, T.; Uchida, A. Methylene blue in place of acridine orange as a photosensitizer in photodynamic therapy of osteosarcoma. In Vivo 2008, 22, 297-303.

4. Huang, Y.Y.; Tanaka, M.; Vecchio, D.; Garcia-Diaz, M.; Chang, J.; Morimoto, Y.; Hamblin, M.R. Photodynamic therapy induces an immune response against a bacterial pathogen. Expert Rev. Clin. Immunol. 2012, 8, 479-494.

5. Maisch, T. A new strategy to destroy antibiotic resistant microorganisms: Antimicrobial photodynamic treatment. Mini Rev. Med. Chem. 2009, 9, 974-983.

6. Giuliani, F.; Martinelli, M.; Cocchi, A.; Arbia, D.; Fantetti, L.; Roncucci, G. In vitro resistance selection studies of $\mathrm{RLP} 068 / \mathrm{Cl}$, a new $\mathrm{Zn}(\mathrm{II})$ phthalocyanine suitable for antimicrobial photodynamic therapy. Antimicrob. Agents Chemother. 2010, 54, 637-642.

7. Diamond, I.; Granelli, S.G.; McDonagh, A.F.; Nielsen, S.; Wilson, C.B.; Jaenicke, R. Photodynamic therapy of malignant tumours. Lancet 1972, 2, 1175-1177.

8. Dougherty, T.J.; Gomer, C.J.; Henderson, B.W.; Jori, G.; Kessel, D.; Korbelik, M.; Moan, J.; Peng, Q. Photodynamic therapy. J. Natl. Cancer Inst. 1998, 90, 889-905.

9. Merchat, M.; Bertolini, G.; Giacomini, P.; Villanueva, A.; Jori, G. Meso-substituted cationic porphyrins as efficient photosensitizers of gram-positive and gram-negative bacteria. J. Photochem. Photobiol. B 1996, 32, 153-157. 
10. Merchat, M.; Spikes, J.D.; Bertoloni, G.; Jori, G. Studies on the mechanism of bacteria photosensitization by meso-substituted cationic porphyrins. J. Photochem. Photobiol. B 1996, 35, $149-157$.

11. Wilson, M.; Burns, T.; Pratten, J.; Pearson, G.J. Bacteria in supragingival plaque samples can be killed by low-power laser light in the presence of a photosensitizer. J. Appl. Bacteriol. 1995, 78, 569-574.

12. Sgolastra, F.; Petrucci, A.; Severino, M.; Graziani, F.; Gatto, R.; Monaco, A. Adjunctive photodynamic therapy to non-surgical treatment of chronic periodontitis: A systematic review and meta-analysis. J. Clin. Periodontol. 2013, 40, 514-526.

13. Passanezi, E.; Damante, C.A.; de Rezende, M.L.; Greghi, S.L. Lasers in periodontal therapy. Periodontology 2000 2015, 67, 268-291.

14. Smiley, C.J.; Tracy, S.L.; Abt, E.; Michalowicz, B.S.; John, M.T.; Gunsolley, J.; Cobb, C.M.; Rossmann, J.; Harrel, S.K.; Forrest, J.L.; et al. Systematic review and meta-analysis on the nonsurgical treatment of chronic periodontitis by means of scaling and root planing with or without adjuncts. J. Am. Dent. Assoc. 2015, 146, 508-524.

15. Bhatti, M.; MacRobert, A.; Henderson, B.; Wilson, M. Exposure of porphyromonas gingivalis to red light in the presence of the light-activated antimicrobial agent toluidine blue decreases membrane fluidity. Curr. Microbiol. 2002, 45, 118-122.

16. Bhatti, M.; MacRobert, A.; Meghji, S.; Henderson, B.; Wilson, M. Effect of dosimetric and physiological factors on the lethal photosensitization of porphyromonas gingivalis in vitro. Photochem. Photobiol. 1997, 65, 1026-1031.

17. Chan, Y.; Lai, C.H. Bactericidal effects of different laser wavelengths on periodontopathic germs in photodynamic therapy. Lasers Med. Sci. 2003, 18, 51-55.

18. Matevski, D.; Weersink, R.; Tenenbaum, H.C.; Wilson, B.; Ellen, R.P.; Lepine, G. Lethal photosensitization of periodontal pathogens by a red-filtered xenon lamp in vitro. J. Periodontal Res. 2003, 38, 428-435.

19. Soukos, N.S.; Ximenez-Fyvie, L.A.; Hamblin, M.R.; Socransky, S.S.; Hasan, T. Targeted antimicrobial photochemotherapy. Antimicrob. Agents Chemother. 1998, 42, 2595-2601.

20. Wilson, M.; Dobson, J.; Sarkar, S. Sensitization of periodontopathogenic bacteria to killing by light from a low-power laser. Oral Microbiol. Immunol. 1993, 8, 182-187.

21. Nagahara, A.; Mitani, A.; Fukuda, M.; Yamamoto, H.; Tahara, K.; Morita, I.; Ting, C.C.; Watanabe, T.; Fujimura, T.; Osawa, K.; et al. Antimicrobial photodynamic therapy using a diode laser with a potential new photosensitizer, indocyanine green-loaded nanospheres, may be effective for the clearance of porphyromonas gingivalis. J. Periodontal Res. 2013, 48, 591-599.

22. Topaloglu, N.; Gulsoy, M.; Yuksel, S. Antimicrobial photodynamic therapy of resistant bacterial strains by indocyanine green and 809-nm diode laser. Photomed. Laser Surg. 2013, 31, 155-162.

23. Klepac-Ceraj, V.; Patel, N.; Song, X.; Holewa, C.; Patel, C.; Kent, R.; Amiji, M.M.; Soukos, N.S. Photodynamic effects of methylene blue-loaded polymeric nanoparticles on dental plaque bacteria. Lasers Surg. Med. 2011, 43, 600-606.

24. Voos, A.C.; Kranz, S.; Tonndorf-Martini, S.; Voelpel, A.; Sigusch, H.; Staudte, H.; Albrecht, V.; Sigusch, B.W. Photodynamic antimicrobial effect of safranine $\mathrm{O}$ on an ex vivo periodontal biofilm. Lasers Surg. Med. 2014, 46, 235-243. 
25. Sarkar, S.; Wilson, M. Lethal photosensitization of bacteria in subgingival plaque from patients with chronic periodontitis. J. Periodontal Res. 1993, 28, 204-210.

26. Dobson, J.; Wilson, M. Sensitization of oral bacteria in biofilms to killing by light from a low-power laser. Arch. Oral Biol. 1992, 37, 883-887.

27. Wood, S.; Nattress, B.; Kirkham, J.; Shore, R.; Brookes, S.; Griffiths, J.; Robinson, C. An in vitro study of the use of photodynamic therapy for the treatment of natural oral plaque biofilms formed in vivo. J. Photochem. Photobiol. B 1999, 50, 1-7.

28. Qin, Y.; Luan, X.; Bi, L.; He, G.; Bai, X.; Zhou, C.; Zhang, Z. Toluidine blue-mediated photoinactivation of periodontal pathogens from supragingival plaques. Lasers Med. Sci. 2008, $23,49-54$.

29. Soukos, N.S.; Mulholland, S.E.; Socransky, S.S.; Doukas, A.G. Photodestruction of human dental plaque bacteria: Enhancement of the photodynamic effect by photomechanical waves in an oral biofilm model. Lasers Surg. Med. 2003, 33, 161-168.

30. Soukos, N.S.; Socransky, S.S.; Mulholland, S.E.; Lee, S.; Doukas, A.G. Photomechanical drug delivery into bacterial biofilms. Pharm. Res. 2000, 17, 405-409.

31. Muller, P.; Guggenheim, B.; Schmidlin, P.R. Efficacy of gasiform ozone and photodynamic therapy on a multispecies oral biofilm in vitro. Eur. J. Oral Sci. 2007, 115, 77-80.

32. O’Neill, J.F.; Hope, C.K.; Wilson, M. Oral bacteria in multi-species biofilms can be killed by red light in the presence of toluidine blue. Lasers Surg. Med. 2002, 31, 86-90.

33. Zeina, B.; Greenman, J.; Purcell, W.M.; Das, B. Killing of cutaneous microbial species by photodynamic therapy. Br. J. Dermatol. 2001, 144, 274-278.

34. Malik, Z.; Ladan, H.; Nitzan, Y. Photodynamic inactivation of gram-negative bacteria: Problems and possible solutions. J. Photochem. Photobiol. B 1992, 14, 262-266.

35. Soukos, N.S.; Som, S.; Abernethy, A.D.; Ruggiero, K.; Dunham, J.; Lee, C.; Doukas, A.G.; Goodson, J.M. Phototargeting oral black-pigmented bacteria. Antimicrob. Agents Chemother. 2005, 49, 1391-1396.

36. Soukos, N.S.; Goodson, J.M. Photodynamic therapy in the control of oral biofilms. Periodontology 2000 2011, 55, 143-166.

37. Zaura-Arite, E.; van Marle, J.; ten Cate, J.M. Conofocal microscopy study of undisturbed and chlorhexidine-treated dental biofilm. J. Dent. Res. 2001, 80, 1436-1440.

38. Del Pozo, J.L.; Patel, R. The challenge of treating biofilm-associated bacterial infections. Clin. Pharmacol. Ther. 2007, 82, 204-209.

39. Cerveny, K.E.; DePaola, A.; Duckworth, D.H.; Gulig, P.A. Phage therapy of local and systemic disease caused by vibrio vulnificus in iron-dextran-treated mice. Infect. Immun. 2002, 70, 6251-6262.

40. Sajjan, U.S.; Tran, L.T.; Sole, N.; Rovaldi, C.; Akiyama, A.; Friden, P.M.; Forstner, J.F.; Rothstein, D.M. P-113d, an antimicrobial peptide active against pseudomonas aeruginosa, retains activity in the presence of sputum from cystic fibrosis patients. Antimicrob. Agents Chemother. 2001, 45, 3437-3444.

41. Tavares, A.; Carvalho, C.M.; Faustino, M.A.; Neves, M.G.; Tome, J.P.; Tome, A.C.; Cavaleiro, J.A.; Cunha, A.; Gomes, N.C.; Alves, E.; et al. Antimicrobial photodynamic therapy: Study of bacterial recovery viability and potential development of resistance after treatment. Mar. Drugs 2010, 8, 91-105. 
42. Tanaka, M.; Mroz, P.; Dai, T.; Huang, L.; Morimoto, Y.; Kinoshita, M.; Yoshihara, Y.; Shinomiya, N.; Seki, S.; Nemoto, K.; et al. Linezolid and vancomycin decrease the therapeutic effect of methylene blue-photodynamic therapy in a mouse model of mrsa bacterial arthritis. Photochem. Photobiol. 2013, 89, 679-682.

43. Azarpazhooh, A.; Shah, P.S.; Tenenbaum, H.C.; Goldberg, M.B. The effect of photodynamic therapy for periodontitis: A systematic review and meta-analysis. J. Periodontol. 2010, 81, 4-14.

44. Watanabe, T.; Fukuda, M.; Mitani, A.; Ting, C.C.; Osawa, K.; Nagahara, A.; Satoh, S.; Fujimura, T.; Takahashi, S.; Iwamura, Y.; et al. Nd:Yag laser irradiation of the tooth root surface inhibits demineralization and root surface softening caused by minocycline application. Photomed. Laser Surg. 2013, 31, 571-577.

45. Adriaens, P.A.; Edwards, C.A.; de Boever, J.A.; Loesche, W.J. Ultrastructural observations on bacterial invasion in cementum and radicular dentin of periodontally diseased human teeth. J. Periodontol. 1988, 59, 493-503.

46. Giuliana, G.; Ammatuna, P.; Pizzo, G.; Capone, F.; D’Angelo, M. Occurrence of invading bacteria in radicular dentin of periodontally diseased teeth: Microbiological findings. J. Clin. Periodontol. 1997, 24, 478-485.

47. Grossi, S.G.; Zambon, J.J.; Ho, A.W.; Koch, G.; Dunford, R.G.; Machtei, E.E.; Norderyd, O.M.; Genco, R.J. Assessment of risk for periodontal disease. I. Risk indicators for attachment loss. J. Periodontol. 1994, 65, 260-267.

48. Galler, C. Periodontal summary score. A new and relevant periodontal assessment guide. J. Ont. Dent. Assoc. 2000, 1, 21-28.

49. Kuo, L.C.; Polson, A.M.; Kang, T. Associations between periodontal diseases and systemic diseases: A review of the inter-relationships and interactions with diabetes, respiratory diseases, cardiovascular diseases and osteoporosis. Public Health 2008, 122, 417-433.

50. Crespi, R.; Barone, A.; Covani, U.; Ciaglia, R.N.; Romanos, G.E. Effects of $\mathrm{CO}_{2}$ laser treatment on fibroblast attachment to root surfaces. A scanning electron microscopy analysis. J. Periodontol. 2002, 73, 1308-1312.

51. Coffelt, D.W.; Cobb, C.M.; MacNeill, S.; Rapley, J.W.; Killoy, W.J. Determination of energy density threshold for laser ablation of bacteria. An in vitro study. J. Clin. Periodontol. 1997, 24, 1-7.

52. Ishikawa, I.; Aoki, A.; Takasaki, A.A.; Mizutani, K.; Sasaki, K.M.; Izumi, Y. Application of lasers in periodontics: True innovation or myth? Periodontology 2000 2009, 50, 90-126.

53. Miyazaki, A.; Yamaguchi, T.; Nishikata, J.; Okuda, K.; Suda, S.; Orima, K.; Kobayashi, T.; Yamazaki, K.; Yoshikawa, E.; Yoshie, H. Effects of $\mathrm{Nd}$ :YAG and $\mathrm{CO}_{2}$ laser treatment and ultrasonic scaling on periodontal pockets of chronic periodontitis patients. J. Periodontol. 2003, 74, 175-180.

54. Ben Hatit, Y.; Blum, R.; Severin, C.; Maquin, M.; Jabro, M.H. The effects of a pulsed Nd:YAG laser on subgingival bacterial flora and on cementum: An in vivo study. J. Clin. Laser Med. Surg. 1996, 14, 137-143.

55. Gold, S.I.; Vilardi, M.A. Pulsed laser beam effects on gingiva. J. Clin. Periodontol. 1994, 21, 391-396. 
56. Dukic, W.; Bago, I.; Aurer, A.; Roguljic, M. Clinical effectiveness of diode laser therapy as an adjunct to non-surgical periodontal treatment: A randomized clinical study. J. Periodontol. 2013, 84, 1111-1117.

57. Kamma, J.J.; Vasdekis, V.G.; Romanos, G.E. The effect of diode laser $(980 \mathrm{~nm})$ treatment on aggressive periodontitis: Evaluation of microbial and clinical parameters. Photomed. Laser Surg. 2009, 27, 11-19.

58. Slot, D.E.; Jorritsma, K.H.; Cobb, C.M.; van der Weijden, F.A. The effect of the thermal diode laser (wavelength $808-980 \mathrm{~nm}$ ) in non-surgical periodontal therapy: A systematic review and meta-analysis. J. Clin. Periodontol. 2014, 41, 681-692.

59. Marques, M.M.; Pereira, A.N.; Fujihara, N.A.; Nogueira, F.N.; Eduardo, C.P. Effect of low-power laser irradiation on protein synthesis and ultrastructure of human gingival fibroblasts. Lasers Surg. Med. 2004, 34, 260-265.

60. Pereira, A.N.; Eduardo Cde, P.; Matson, E.; Marques, M.M. Effect of low-power laser irradiation on cell growth and procollagen synthesis of cultured fibroblasts. Lasers Surg. Med. 2002, 31, 263-267.

61. Amorim, J.C.; de Sousa, G.R.; de Barros Silveira, L.; Prates, R.A.; Pinotti, M.; Ribeiro, M.S. Clinical study of the gingiva healing after gingivectomy and low-level laser therapy. Photomed. Laser Surg. 2006, 24, 588-594.

62. Dogan, G.E.; Demir, T.; Orbak, R. Effect of low-level laser on guided tissue regeneration performed with equine bone and membrane in the treatment of intrabony defects: A clinical study. Photomed. Laser Surg. 2014, 32, 226-231.

63. Folwaczny, M.; Aggstaller, H.; Mehl, A.; Hickel, R. Removal of bacterial endotoxin from root surface with ER:YAG laser. Am. J. Dent. 2003, 16, 3-5.

64. Schwarz, F.; Bieling, K.; Venghaus, S.; Sculean, A.; Jepsen, S.; Becker, J. Influence of fluorescence-controlled ER:YAG laser radiation, the vector system and hand instruments on periodontally diseased root surfaces in vivo. J. Clin. Periodontol. 2006, 33, 200-208.

65. Watanabe, H.; Ishikawa, I.; Suzuki, M.; Hasegawa, K. Clinical assessments of the erbium:YAG laser for soft tissue surgery and scaling. J. Clin. Laser Med. Surg. 1996, 14, 67-75.

66. Bonito, A.J.; Lux, L.; Lohr, K.N. Impact of local adjuncts to scaling and root planing in periodontal disease therapy: A systematic review. J. Periodontol. 2005, 76, 1227-1236.

67. De Almeida, J.M.; Theodoro, L.H.; Bosco, A.F.; Nagata, M.J.; Bonfante, S.; Garcia, V.G. Treatment of experimental periodontal disease by photodynamic therapy in rats with diabetes. J. Periodontol. 2008, 79, 2156-2165.

68. De Almeida, J.M.; Theodoro, L.H.; Bosco, A.F.; Nagata, M.J.; Oshiiwa, M.; Garcia, V.G. Influence of photodynamic therapy on the development of ligature-induced periodontitis in rats. J. Periodontol. 2007, 78, 566-575.

69. Braun, A.; Dehn, C.; Krause, F.; Jepsen, S. Short-term clinical effects of adjunctive antimicrobial photodynamic therapy in periodontal treatment: A randomized clinical trial. J. Clin. Periodontol. 2008, 35, 877-884.

70. Meisel, P.; Kocher, T. Photodynamic therapy for periodontal diseases: State of the art. J. Photochem. Photobiol. B 2005, 79, 159-170. 
71. Wilson, M. Photolysis of oral bacteria and its potential use in the treatment of caries and periodontal disease. J. Appl. Bacteriol. 1993, 75, 299-306.

72. Hamblin, M.R.; Hasan, T. Photodynamic therapy: A new antimicrobial approach to infectious disease? Photochem. Photobiol. Sci. 2004, 3, 436-450.

73. Qin, Y.L.; Luan, X.L.; Bi, L.J.; Sheng, Y.Q.; Zhou, C.N.; Zhang, Z.G. Comparison of toluidine blue-mediated photodynamic therapy and conventional scaling treatment for periodontitis in rats. J. Periodontal Res. 2008, 43, 162-167.

74. Maisch, T. Anti-microbial photodynamic therapy: Useful in the future? Lasers Med. Sci. 2007, $22,83-91$.

75. Christodoulides, N.; Nikolidakis, D.; Chondros, P.; Becker, J.; Schwarz, F.; Rossler, R.; Sculean, A. Photodynamic therapy as an adjunct to non-surgical periodontal treatment: A randomized, controlled clinical trial. J. Periodontol. 2008, 79, 1638-1644.

76. Chondros, P.; Nikolidakis, D.; Christodoulides, N.; Rossler, R.; Gutknecht, N.; Sculean, A. Photodynamic therapy as adjunct to non-surgical periodontal treatment in patients on periodontal maintenance: A randomized controlled clinical trial. Lasers Med. Sci. 2009, 24, 681-688.

77. Lulic, M.; Leiggener Gorog, I.; Salvi, G.E.; Ramseier, C.A.; Mattheos, N.; Lang, N.P. One-year outcomes of repeated adjunctive photodynamic therapy during periodontal maintenance: A proof-of-principle randomized-controlled clinical trial. J. Clin. Periodontol. 2009, 36, 661-666.

78. Betsy, J.; Prasanth, C.S.; Baiju, K.V.; Prasanthila, J.; Subhash, N. Efficacy of antimicrobial photodynamic therapy in the management of chronic periodontitis: A randomized controlled clinical trial. J. Clin. Periodontol. 2014, 41, 573-581.

79. Sgolastra, F.; Petrucci, A.; Gatto, R.; Marzo, G.; Monaco, A. Photodynamic therapy in the treatment of chronic periodontitis: A systematic review and meta-analysis. Lasers Med. Sci. 2013, 28, 669-682.

80. Atieh, M.A. Photodynamic therapy as an adjunctive treatment for chronic periodontitis: A meta-analysis. Lasers Med. Sci. 2010, 25, 605-613.

81. De Almeida, J.M.; Theodoro, L.H.; Bosco, A.F.; Nagata, M.J.; Oshiiwa, M.; Garcia, V.G. In vivo effect of photodynamic therapy on periodontal bone loss in dental furcations. J. Periodontol. 2008, 79, 1081-1088.

82. Garcia, V.G.; Longo, M.; Fernandes, L.A.; Gualberto, E.C., Jr.; Santinoni Cdos, S.; Bosco, A.F.; Nagata, M.J.; Theodoro, L.H. Treatment of experimental periodontitis in rats using repeated adjunctive antimicrobial photodynamic therapy. Lasers Med. Sci. 2013, 28, 143-150.

83. Garcia, V.G.; Gualberto Junior, E.C.; Fernandes, L.A.; Bosco, A.F.; Hitomi Nagata, M.J.; Casatti, C.A.; Ervolino, E.; Theodoro, L.H. Adjunctive antimicrobial photodynamic treatment of experimentally induced periodontitis in rats with ovariectomy. J. Periodontol. 2013, 84, 556-565.

84. Garcia, V.G.; Longo, M.; Gualberto Junior, E.C.; Bosco, A.F.; Nagata, M.J.; Ervolino, E.; Theodoro, L.H. Effect of the concentration of phenothiazine photosensitizers in antimicrobial photodynamic therapy on bone loss and the immune inflammatory response of induced periodontitis in rats. J. Periodontal Res. 2014, 49, 584-594.

85. Sigusch, B.W.; Pfitzner, A.; Albrecht, V.; Glockmann, E. Efficacy of photodynamic therapy on inflammatory signs and two selected periodontopathogenic species in a beagle dog model. J. Periodontol. 2005, 76, 1100-1105. 
86. De Oliveira, R.R.; Novaes, A.B., Jr.; Garlet, G.P.; de Souza, R.F.; Taba, M., Jr.; Sato, S.; de Souza, S.L.; Palioto, D.B.; Grisi, M.F.; Feres, M. The effect of a single episode of antimicrobial photodynamic therapy in the treatment of experimental periodontitis. Microbiological profile and cytokine pattern in the dog mandible. Lasers Med. Sci. 2011, 26, 359-367.

87. Prates, R.A.; Yamada, A.M.; Suzuki, L.C.; Franca, C.M.; Cai, S.; Mayer, M.P.; Ribeiro, A.C.; Ribeiro, M.S. Histomorphometric and microbiological assessment of photodynamic therapy as an adjuvant treatment for periodontitis: A short-term evaluation of inflammatory periodontal conditions and bacterial reduction in a rat model. Photomed. Laser Surg. 2011, 29, 835-844.

88. Soukos, N.S.; Wilson, M.; Burns, T.; Speight, P.M. Photodynamic effects of toluidine blue on human oral keratinocytes and fibroblasts and streptococcus sanguis evaluated in vitro. Lasers Surg. Med. 1996, 18, 253-259.

89. Houreld, N.; Abrahamse, H. In vitro exposure of wounded diabetic fibroblast cells to a helium-neon laser at 5 and $16 \mathrm{~J} / \mathrm{cm}^{2}$. Photomed. Laser Surg. 2007, 25, 78-84.

90. Tanaka, M.; Mroz, P.; Dai, T.; Huang, L.; Morimoto, Y.; Kinoshita, M.; Yoshihara, Y.; Nemoto, K.; Shinomiya, N.; Seki, S.; et al. Photodynamic therapy can induce a protective innate immune response against murine bacterial arthritis via neutrophil accumulation. PLoS ONE 2012, 7, e39823, doi:10.1371/journal.pone.0039823.

91. Braham, P.; Herron, C.; Street, C.; Darveau, R. Antimicrobial photodynamic therapy may promote periodontal healing through multiple mechanisms. J. Periodontol. 2009, 80, 1790-1798.

92. Seguier, S.; Souza, S.L.; Sverzut, A.C.; Simioni, A.R.; Primo, F.L.; Bodineau, A.; Correa, V.M.; Coulomb, B.; Tedesco, A.C. Impact of photodynamic therapy on inflammatory cells during human chronic periodontitis. J. Photochem. Photobiol. B 2010, 101, 348-354.

93. Fujimura, T.; Mitani, A.; Fukuda, M.; Mogi, M.; Osawa, K.; Takahashi, S.; Aino, M.; Iwamura, Y.; Miyajima, S.; Yamamoto, H.; et al. Irradiation with a low-level diode laser induces the developmental endothelial locus-1 gene and reduces proinflammatory cytokines in epithelial cells. Lasers Med. Sci. 2014, 29, 987-994.

94. Novaes, A.B., Jr.; Schwartz-Filho, H.O.; de Oliveira, R.R.; Feres, M.; Sato, S.; Figueiredo, L.C. Antimicrobial photodynamic therapy in the non-surgical treatment of aggressive periodontitis: Microbiological profile. Lasers Med. Sci. 2012, 27, 389-395.

95. De Oliveira, R.R.; Schwartz-Filho, H.O.; Novaes, A.B.; Garlet, G.P.; de Souza, R.F.; Taba, M.; Scombatti de Souza, S.L.; Ribeiro, F.J. Antimicrobial photodynamic therapy in the non-surgical treatment of aggressive periodontitis: Cytokine profile in gingival crevicular fluid, preliminary results. J. Periodontol. 2009, 80, 98-105.

96. De Oliveira, R.R.; Schwartz-Filho, H.O.; Novaes, A.B., Jr.; Taba, M., Jr. Antimicrobial photodynamic therapy in the non-surgical treatment of aggressive periodontitis: A preliminary randomized controlled clinical study. J. Periodontol. 2007, 78, 965-973.

97. Moreira, A.L.; Novaes, A.B., Jr.; Grisi, M.F.; Taba, M., Jr.; Souza, S.L.; Palioto, D.B.; de Oliveira, P.G.; Casati, M.Z.; Casarin, R.C.; Messora, M.R. Antimicrobial photodynamic therapy as an adjunct to non-surgical treatment of aggressive periodontitis: A split-mouth randomized controlled trial. J. Periodontol. 2015, 86, 376-386. 
98. Vohra, F.; Akram, Z.; Safi, S.H.; Devi Vaithilingam, R.; Ghanem, A.; Sergis, K.; Javed, F. Role of antimicrobial photodynamic therapy in the treatment of aggressive periodontitis: A systematic review. Photodiagnosis Photodyn. Ther. 2015, doi:10.1016/j.pdpdt.2015.06.010.

99. Noro Filho, G.A.; Casarin, R.C.; Casati, M.Z.; Giovani, E.M. PDT in non-surgical treatment of periodontitis in HIV patients: A split-mouth, randomized clinical trial. Lasers Surg. Med. 2012, 44, 296-302.

100. Soga, Y.; Saito, T.; Nishimura, F.; Ishimaru, F.; Mineshiba, J.; Mineshiba, F.; Takaya, H.; Sato, H.; Kudo, C.; Kokeguchi, S.; et al. Appearance of multidrug-resistant opportunistic bacteria on the gingiva during leukemia treatment. J. Periodontol. 2008, 79, 181-186.

101. Aimetti, M.; Romano, F.; Torta, I.; Cirillo, D.; Caposio, P.; Romagnoli, R. Debridement and local application of tetracycline-loaded fibres in the management of persistent periodontitis: Results after 12 months. J. Clin. Periodontol. 2004, 31, 166-172.

102. Bondan, E.F.; Lallo, M.A.; Baz, E.I.; Sinhorini, I.L.; Graca, D.L. Ultrastructural study of the remyelinating process following local ethidium bromide injection in the brainstem of dexamethasone-immunosuppressed rats (in Portuguese). Arq. Neuropsiquiatr. 2004, 62, 131-138.

103. Pessoa, E.S.; Melhado, R.M.; Theodoro, L.H.; Garcia, V.G. A histologic assessment of the influence of low-intensity laser therapy on wound healing in steroid-treated animals. Photomed. Laser Surg. 2004, 22, 199-204.

104. Tenius, F.P.; Biondo-Simões, M.L.P.; Ioshii, S.O. Effects of chronic use of dexamethasone on cutaneous wound healing in rats. An. Bras. Dermatol. 2007, 82, 141-149.

105. Bottura, P.E.; Milanezi, J.; Fernandes, L.A.; Caldas, H.C.; Abbud-Filho, M.; Garcia, V.G.; Baptista, M.A. Nonsurgical periodontal therapy combined with laser and photodynamic therapies for periodontal disease in immunosuppressed rats. Transplant. Proc. 2011, 43, 2009-2016.

106. Fernandes, L.A.; de Almeida, J.M.; Theodoro, L.H.; Bosco, A.F.; Nagata, M.J.; Martins, T.M.; Okamoto, T.; Garcia, V.G. Treatment of experimental periodontal disease by photodynamic therapy in immunosuppressed rats. J. Clin. Periodontol. 2009, 36, 219-228.

107. Fernandes, L.A.; Martins, T.M.; de Almeida, J.M.; Theodoro, L.H.; Garcia, V.G. Radiographic assessment of photodynamic therapy as an adjunctive treatment on induced periodontitis in immunosuppressed rats. J. Appl. Oral Sci. 2010, 18, 237-243.

108. Garcia, V.G.; Fernandes, L.A.; de Almeida, J.M.; Bosco, A.F.; Nagata, M.J.; Martins, T.M.; Okamoto, T.; Theodoro, L.H. Comparison between laser therapy and non-surgical therapy for periodontitis in rats treated with dexamethasone. Lasers Med. Sci. 2010, 25, 197-206.

(C) 2015 by the authors; licensee MDPI, Basel, Switzerland. This article is an open access article distributed under the terms and conditions of the Creative Commons Attribution license (http://creativecommons.org/licenses/by/4.0/). 